\title{
Co-inoculation of Azospirillum brasilense and Herbaspirillum seropedicae in maize
}

\author{
Janaína Dartora $^{1}$, Deniele Marini ${ }^{2}$, Edilaine. D. V. Gonçalves ${ }^{2} \&$ Vandeir F. Guimarães $^{3}$ \\ ${ }^{1}$ Instituto Agronômico do Paraná/Área de Produção e Experimentação. Pato Branco, PR. E-mail: janaina_dartora@yahoo.com.br (Corresponding author) \\ ${ }^{2}$ Universidade Estadual do Oeste do Paraná. Marechal Cândido Rondon, PR. E-mail: denielemarini@yahoo.com.br; edilainevalentina@gmail.com \\ ${ }^{3}$ Universidade Estadual do Oeste do Paraná/Centro de Ciências Agrárias/Curso de Agronomia. Marechal Cândido Rondon, PR. E-mail: vandeirfg@yahoo.com.br
}

\section{Key words:}

Zea mays L. growth-promoting bacteria phytohormones

\begin{abstract}
A B S T R A C T
Bacteria from the genera Azospirillum and Herbaspirillum have been associated with increments in maize yield. The aim of this study was to evaluate the maize yield and nutritional content in response to inoculation with $A$. brasilense and $H$. seropediceae in association with nitrogen $(\mathrm{N})$ fertilization. The experimental design was randomized blocks in a $4 \mathrm{x} 5$ factorial scheme, with four replicates. The treatments consisted of seed inoculation (control without $\mathrm{N}$ and inoculation, $A$. brasilense strain - AbV5, H. seropediceae strain SMR1 and co-inoculation AbV5 + SMR1) and $\mathrm{N}$ doses (0, 40, 80, 120 and $\left.160 \mathrm{~kg} \mathrm{ha}^{-1}\right)$. The following variables were evaluated: ear insertion height, ear length, ear diameter, number of rows per ear, number of grains per row, ear weight, yield and NPK contents in leaves and grains. There was no interaction between the factors studied. Co-inoculation with the strains promoted increments of $12 \%$ in leaf $\mathrm{P}$ content, compared with control, and $\mathrm{N}$ fertilization promoted increase in yield and leaf $\mathrm{P}$ content up to the maximum dose studied.
\end{abstract}

\section{Palavras-chave:}

Zea mays L. bactérias promotoras do crescimento fito-hormônios

\section{Co-inoculação de Azospirillum brasilense e Herbaspirilum seropediceae na cultura do milho}

\begin{abstract}
R E S U M O
Bactérias dos gêneros Azospirillum e Herbaspirillum têm sido associadas à obtenção de incrementos na produtividade do milho. O objetivo deste estudo foi avaliar a produtividade e o teor nutricional do milho em resposta à inoculação de $A$. brasilense e H. seropedicae em associação com a adubação nitrogenada. $O$ experimento foi conduzido em delineamento experimental de blocos ao acaso em esquema fatorial 4 x 5 com quatro repetições. Os tratamentos foram constituídos da inoculação de sementes (controle - sem $\mathrm{N}$ e sem inoculação, estirpe de A. brasilense - AbV5, estirpe de H. seropedicae - SmR1 e coinoculação AbV5 + SmR1) e doses de N (0, 40, 80, 120 e $\left.160 \mathrm{~kg} \mathrm{ha}^{-1} \mathrm{~N}\right)$. Foram avaliados: altura de inserção da espiga, comprimento e diâmetro da espiga, número de fileiras por espiga e de grãos por fileira, massa de espiga, produtividade e teores de NPK em folhas e grãos. Não houve interação entre os fatores em estudo. A coinoculação de estirpes proporcionou incremento de $12 \%$ no teor de $\mathrm{P}$ foliar em relação ao controle e a adubação nitrogenada proporcionou incremento na produtividade e teor de $\mathrm{P}$ foliar até a máxima dose estudada.
\end{abstract}




\section{INTRODUCTION}

Maize (Zea mays L.) constitutes an essential raw material in the manufacturing of a wide range of products, standing out as the main cereal produced in Brazil.

Besides the participation in plant physiological processes, the supply of nitrogen $(\mathrm{N})$ can affect maize growth and yield through alterations related to leaf area expansion and photosynthetic capacity (Gava et al., 2010). However, inadequate use and the high cost of $\mathrm{N}$ fertilizers have led to the research and development of new technologies aiming to establish a more sustainable agricultural production system. In this context, the association of growth-promoting bacteria from the genera Azospirillum and Herbaspirillum with grass crops of economic interest has stood out for benefiting plants through various mechanisms, such as biological $\mathrm{N}$ fixation (BNF), production of phytohormones and solubilization of phosphates (Bashan \& De-Bashan, 2010). Field studies have demonstrated the potential of isolated inoculation of $A$. brasilense and $H$. seropedicae to promote increments in maize grain yield (Hungria et al., 2010; Lana et al., 2012; Alves et al., 2015). In spite of that, the co-inoculation of different microorganisms needs to be explored, because it consists in an alternative of advance in the studies, as a strategy for the production of efficient inoculants due to the intensification of the beneficial effects on plants (Bashan \& Holguin, 1997). Thus, this study aimed to evaluate maize yield and nutritional content in response to the co-inoculation of $A$. brasilense and $H$. seropedicae in association with $\mathrm{N}$ fertilization.

\section{MAterial ANd Methods}

The experiment was carried out in the 2010/2011 summer season, in Marechal Cândido Rondon-PR, Brazil (54 22' W; $24^{\circ} 46^{\prime} \mathrm{S} ; 420 \mathrm{~m}$ ). The monthly data of rainfall and minimum, maximum and mean air temperature along the experiment are shown in Figure 1.

The experiment was set in a randomized block design with four replicates, in a $4 \times 5$ factorial scheme, in which the first factor refers to seed inoculation: control (without $\mathrm{N}$ and without inoculation), strain of $A$. brasilense (AbV5), strain of H. seropediceae (SmR1) and co-inoculation of both strains

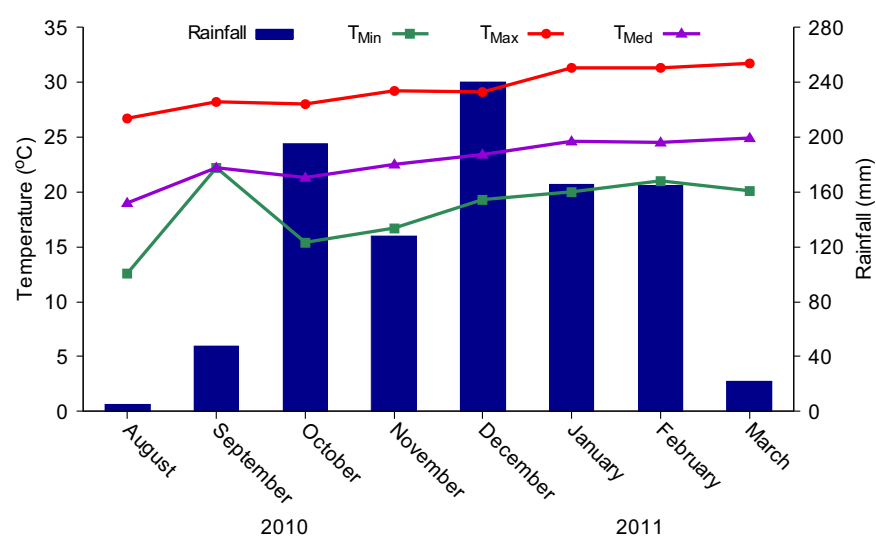

Figure 1. Cumulative rainfall and minimum, maximum and mean air temperature per month from August 2010 to March 2011 in the municipality of Marechal Cândido Rondon-PR, Brazil
(AbV5 + SmR1), while the second factor comprehended $\mathrm{N}$ fertilization doses: $0,40,80,120$ and $160 \mathrm{~kg} \mathrm{ha}^{-1}$.

Inoculants were prepared from a pure bacterial solution at the concentration of $1 \times 10^{9}$ cells $\mathrm{mL}^{-1}$. Inoculation was performed before sowing at the proportion of $1 \mathrm{~mL}$ of inoculant for 1,000 seeds, using half of this proportion $(0.5 \mathrm{~mL})$ of inoculant of each strain for the co-inoculation.

Sowing was performed using handheld maize planters ("matracas") on October 6, 2010, with the single hybrid 30R50 Herculex $^{\circledR}$ and each experimental unit consisted of six 5-m-long rows, with five plants per linear meter and $0.70 \mathrm{~m}$ between rows. Fertilization at sowing consisted of $40 \mathrm{~kg} \mathrm{ha}^{-1}$ of $\mathrm{P}_{2} \mathrm{O}_{5}, 50$ $\mathrm{kg} \mathrm{ha}^{-1}$ of $\mathrm{K}_{2} \mathrm{O}$ and $30 \mathrm{~kg} \mathrm{ha}^{-1}$ of $\mathrm{N}$; treatments without $\mathrm{N}$ did not receive $\mathrm{N}$ fertilization. The rest of the $\mathrm{N}$ dose, according to the treatments, was applied as top-dressing in the V6 stage, using urea as the $\mathrm{N}$ source ( $46 \%$ of $\mathrm{N}$ ).

During the experiment, herbicides selective for maize with the active ingredients triazine $\left(5.0 \mathrm{~L} \mathrm{ha}^{-1}\right)$ and nicosulfuron $\left(1.5 \mathrm{~L} \mathrm{ha}^{-1}\right)$ were applied in the vegetative stage. In addition, two insecticide applications were performed, at 18 and 30 days after sowing, using a product containing thiamethoxam + lambdacyhalothrin as active ingredients $\left(0.25 \mathrm{~L} \mathrm{ha}^{-1}\right)$.

For the determination of contents of N, phosphorus (P) and potassium (K), leaf tissues were collected in the R1 stage (appearance of style-stigmas), according to the methodology proposed by Malavolta et al. (1997). The collected leaves were dried in a forced-air oven at $55^{\circ} \mathrm{C} \pm 2{ }^{\circ} \mathrm{C}$ for $72 \mathrm{~h}$ and ground in a Wiley-type mill. Leaf $\mathrm{N}$ and $\mathrm{P}$ contents were determined according to methodologies described by Tedesco et al. (1995) and Braga \& Defelipo (1974), while K contents were determined through flame photometry.

Maize harvest was manually performed on March 15, 2011, by collecting the ears from the evaluation area of the plot (two 3-m-long central rows) for the determination of yield after correcting grain moisture to $13 \%$ (wet basis). Before harvest, ear insertion height was also evaluated; random samples of 10 ears per plot were used for the evaluation of: ear length, ear diameter, number of rows per ear, number of grains per row and ear weight. Grain samples were ground in a knife mill and sieved (2-mm mesh) for the determination of N, P and $\mathrm{K}$ contents.

The data were subjected to analysis of variance using the program Sisvar (Ferreira, 2008) and means were compared by Tukey test ( $\mathrm{p} \leq 0.05)$. Regression analysis, through Student's $\mathrm{t}$-test, was applied for the responses of the variables to $\mathrm{N}$ doses.

\section{Results AND Discussion}

There was no significant interaction between the inoculation of $A$. brasilense and $H$. seropedicae with $\mathrm{N}$ fertilization for the evaluated characteristics (Table 1).

Ear insertion height was influenced by inoculation and the control treatment showed higher mean in relation to the co-inoculation of strains of $A$. brasilense and $H$. seropediceae, but it did not differ from the isolated inoculation (Table 2). Considering the influence of the environment on plant height (Albuquerque et al., 2013), co-inoculation may have promoted greater plant growth in diameter and lower growth in length, 
Table 1. Summary of the analysis of variance for ear insertion height (EIH), ear length (EL), ear diameter (ED), number of rows per ear (NRE), number of grains per row (NGR), ear weight (EW), grain yield (YIELD) and contents of $N$, $P$ and $\mathrm{K}$ in the leaves (NL, PL and $\mathrm{KL}$ ) and in the grains (NG, PG and KG) of the maize hybrid 30R50, as a function of inoculation with strains of $A$. brasilense (AbV5) and $H$. seropedicae (SmR1), isolated and in combination, associated with nitrogen $(\mathrm{N})$ fertilization

\begin{tabular}{|c|c|c|c|c|c|c|c|c|c|c|c|c|c|c|}
\hline \multirow{2}{*}{ SV } & \multirow{2}{*}{ DF - } & \multicolumn{13}{|c|}{ Mean squares } \\
\hline & & EIH & EL & ED & NRE & NGR & EW & YIELD & $\mathrm{NL}$ & PL & $\mathrm{KL}$ & NG & PG & KG \\
\hline Block & 3 & 591.59 & 1.32 & 2.63 & 0.08 & 5.81 & 1215.41 & 1226825 & 25.31 & 0.23 & 909.34 & 1.80 & 0.50 & 0.97 \\
\hline Inoculant & 3 & $143.28 * *$ & $4.28^{\star \star}$ & $6.93^{\star \star}$ & $0.08^{\mathrm{ns}}$ & $6.63^{\mathrm{ns}}$ & 2894.04 ** & 4103749 ns & $34.01^{\text {ns }}$ & $0.60^{*}$ & $36.58^{\text {ns }}$ & $64.78^{*}$ & $0.18^{\mathrm{ns}}$ & $1.16^{\mathrm{ns}}$ \\
\hline $\mathrm{N}$ doses & 4 & $128.02^{\star \star}$ & $1.50 *$ & $6.63^{\star \star}$ & $1.08^{\mathrm{ns}}$ & $4.29^{\mathrm{ns}}$ & $2204.79 *$ & 9443146 ** & $17.53^{\mathrm{ns}}$ & $0.68^{* *}$ & $14.87^{\mathrm{ns}}$ & $22.78^{\mathrm{ns}}$ & $0.25^{\mathrm{ns}}$ & $1.92^{\text {ns }}$ \\
\hline IXN & 12 & $37.46^{\mathrm{ns}}$ & $0.22^{\mathrm{ns}}$ & $1.56^{\mathrm{ns}}$ & $1.98^{\mathrm{ns}}$ & $2.87^{\mathrm{ns}}$ & $466.03^{\mathrm{ns}}$ & $1313974^{\text {ns }}$ & $13.36^{\mathrm{ns}}$ & $0.18^{\mathrm{ns}}$ & $9.32^{\mathrm{ns}}$ & $14.94^{\mathrm{ns}}$ & $0.14^{\mathrm{ns}}$ & $0.51^{\text {ns }}$ \\
\hline Residue & 57 & 33.82 & 0.47 & 0.81 & 1.18 & 3.47 & 647.12 & 1805781 & 14.13 & 0.17 & 21.95 & 19.38 & 0.20 & 1.06 \\
\hline CV (\%) & & 4.29 & 3.62 & 1.72 & 6.88 & 4.75 & 9.56 & 13.84 & 12.0 & 12.08 & 8.94 & 33.6 & 23.01 & 6.85 \\
\hline
\end{tabular}

*, ${ }^{*}$ Significant at 0.05 and 0.01 by F test; ns Not significant; SV - Source of variation; DF - Degrees of freedom; CV - Coefficient of variation

Table 2. Ear insertion height $(E I H)$, ear length (EL), ear diameter (ED), number of rows per ear (NRE), number of grains per row (NGR), ear weight (EW), grain yield (YIELD) and contents of $N, P$ and $K$ in the leaves (NL, PL and KL) and in the grains (NG, PG and KG) of the maize hybrid 30R50, as a function of the inoculation of seeds with the strains of $A$. brasilense (AbV5) and $H$. seropedicae (SmR1), isolated and in combination

\begin{tabular}{|c|c|c|c|c|c|c|c|c|c|c|c|c|c|}
\hline \multirow{2}{*}{ Treatment } & EIH & EL & \multirow{2}{*}{$\begin{array}{c}\text { ED } \\
\mathrm{Mm}\end{array}$} & \multirow{2}{*}{ NRE } & \multirow{2}{*}{ NGR } & \multirow{2}{*}{$\begin{array}{c}\text { EW } \\
\text { g }\end{array}$} & \multirow{2}{*}{$\begin{array}{l}\text { YIELD } \\
\mathrm{kg} \mathrm{ha}^{-1}\end{array}$} & \multirow{2}{*}{ NL } & \multirow{2}{*}{ NG } & \multirow{2}{*}{ PL } & \multirow{2}{*}{$P G$} & \multirow{2}{*}{ KL } & \multirow{2}{*}{ KG } \\
\hline & & & & & & & & & & & & & \\
\hline Control & $138 \mathrm{a}$ & $18 b$ & $52 \mathrm{~b}$ & $16 a$ & $39 a$ & 252 b & $12,651 \mathrm{a}$ & $30 \mathrm{a}$ & $13 a b$ & $3.2 \mathrm{~b}$ & $2.0 \mathrm{a}$ & $54 \mathrm{a}$ & $15 a$ \\
\hline AbV5 & $137 a b$ & $18 \mathrm{~b}$ & $52 \mathrm{~b}$ & $16 a$ & $39 a$ & $260 a b$ & $12,537 \mathrm{a}$ & $32 \mathrm{a}$ & $11 \mathrm{~b}$ & $3.3 \mathrm{ab}$ & $1.8 \mathrm{a}$ & $53 a$ & $15 a$ \\
\hline SmR1 & $135 \mathrm{ab}$ & $19 a$ & $53 a$ & $16 \mathrm{a}$ & $39 a$ & $277 a$ & $12,905 \mathrm{a}$ & $30 \mathrm{a}$ & $12 a b$ & $3.6 \mathrm{a}$ & $2.0 \mathrm{a}$ & $52 \mathrm{a}$ & $15 a$ \\
\hline AbV5 + SmR1 & $132 \mathrm{~b}$ & $19 \mathrm{a}$ & $53 a$ & $16 \mathrm{a}$ & $40 \mathrm{a}$ & $275 a$ & $13,573 \mathrm{a}$ & $33 a$ & $16 \mathrm{a}$ & $3.5 a b$ & $2.0 \mathrm{a}$ & $51 \mathrm{a}$ & $15 a$ \\
\hline Mean & 136 & 19 & 52 & 16 & 39 & 266 & 12,916 & 31 & 13 & 3.4 & 2.0 & 52 & 15 \\
\hline CV (\%) & 4.29 & 3.62 & 1.72 & 6.88 & 4.75 & 9.56 & 12.77 & 12.00 & 33.60 & 12.08 & 23.01 & 8.94 & 6.85 \\
\hline
\end{tabular}

Means followed by the same letter in the column do not differ significantly by Tukey test, $p<0.05$; CV - Coefficient of variation

thus reducing ear insertion height. This is due to the production of phytohormones that stimulate root development and the absorption of nutrients by the plant (Dobbelaere et al., 2003; Alves et al., 2015). The reduction in ear insertion height is considered as advantageous for maize, because it facilitates mechanized harvest and reduces plant lodging (Casagrande \& Fornasieri Filho, 2002).

For ear length and diameter, higher means were observed for the inoculation of $H$. seropediceae, isolated or combined with A. brasilense, in relation to the control and to the inoculation of $A$. brasilense (Table 2). H. seropedicae is a microorganism highly specialized in colonizing the inside of the plants with an efficient colonization pattern (Monteiro et al., 2008). This favors the plant-bacteria interaction and represents an ecological advantage over bacteria such as Azospirillum, which usually colonize superficial plant parts.

For the number of rows per ear and grains per row, there was no effect of inoculation due to the influence of the genetic factor on these characteristics, with mean values of 16 and 39, respectively. For ear weight, the inoculation of $H$. seropediceae, isolated or combined with $A$. brasilense, surpassed the control with increments of 10 and $9 \%$, respectively; however, it did not differ from the isolated inoculation of $A$. brasilense (Table 2).

Grain yield was not influenced by inoculation and an overall mean yield of $12,916 \mathrm{~kg} \mathrm{ha}^{-1}$ (Table 2) was obtained, which is considered as high compared with the mean yield obtained in the 2010/2011 season in the state of Paraná, 7,884 kg ha-1 (SEAB, 2011). The high yield obtained in the present study can be attributed to a set of factors that favored crop development, such as genetic characteristics of the hybrid, adequate management practices and favorable climatic conditions (air temperature and rainfall) along the experiment (Figure 1).
Despite the lack of significant effect, the co-inoculation of the strains of $H$. seropediceae and A. brasilense promoted mean yield of $13,573 \mathrm{~kg} \mathrm{ha}^{-1}$, with increment of $922 \mathrm{~kg} \mathrm{ha}^{-1}$ in relation to the control $\left(12,651 \mathrm{~kg} \mathrm{ha}^{-1}\right)$. Reis Júnior et al. (2008) reported positive response of maize to co-inoculation of Azospirillum and Herbaspirillum. These authors evaluated, in greenhouse, the performance of isolated and combined inoculation of the strains of $A$. amazonense and $H$. seropediceae and observed that co-inoculated plants showed higher shoot and root dry matter production, with increments of about $40 \%$ in relation to the control, due to the production of growth-promoting substances (phytohormones) by the bacteria.

The production of phytohormones is considered as the main responsible for the positive response of plants to coinoculation of growth-promoting bacteria, for stimulating alterations in the morphology of the root system (Bashan \& De-Bashan, 2010), causing increase in the number of root hairs and mean diameter of lateral and adventitious roots (Dobbelaere et al., 2003; Bárbaro et al., 2008).

The influence of $H$. seropediceae on the increment in ear length and weight, regardless of the inoculation of $A$. brasilense, may have contributed to the positive effect of co-inoculation on grain yield. It is possible to infer that plant colonization by Herbaspirillum, an obligatory endophyte, has intensified the effects of inoculation, since the establishment inside sites protected from oxygen allows microorganisms to express their maximum potential for BNF (Kennedy et al., 1997). Additionally, the inside of the plants represents a habitat free from unfavorable environmental conditions, which allows a more efficient transfer of compounds between microorganisms and plants (Bashan \& De-Bashan, 2010). 
As to leaf P content, there was an increment of $12 \%$ for the treatment inoculated with $H$. seropediceae in relation to the control, without differing from the inoculation of $A$. brasilense or the combination of both strains (Table 2). Leaf P contents are close to the highest value established by Malavolta et al. (1997) for the maize sufficiency range (2.5 to $3.5 \mathrm{~g} \mathrm{~kg}^{-1}$ of P). On the other hand, $\mathrm{P}$ content in the grains was not influenced by inoculation and showed mean value of $2.0 \mathrm{~g} \mathrm{~kg}^{-1}$.

There was no influence of inoculation on leaf $\mathrm{N}$ content, which showed mean value of $31 \mathrm{~g} \mathrm{~kg}^{-1}$ (Table 2), within the sufficiency range considered by Malavolta et al. (1997) as adequate for maize (27.5 to $32.5 \mathrm{~g} \mathrm{~kg}^{-1}$ of $\left.\mathrm{N}\right)$. Dotto et al. (2010) also found no influence of inoculation with $H$. seropedicae on leaf $\mathrm{N}$ content. As to $\mathrm{N}$ content in the grains, higher mean was observed for the co-inoculation of both strains in relation to the isolated inoculation of $A$. brasilense, and similar to the other treatments. Reis Júnior et al. (2008) associated the positive effect of co-inoculation of Azospirillum and Herbaspirillum on leaf $\mathrm{N}$ content in maize plants to BNF

A.

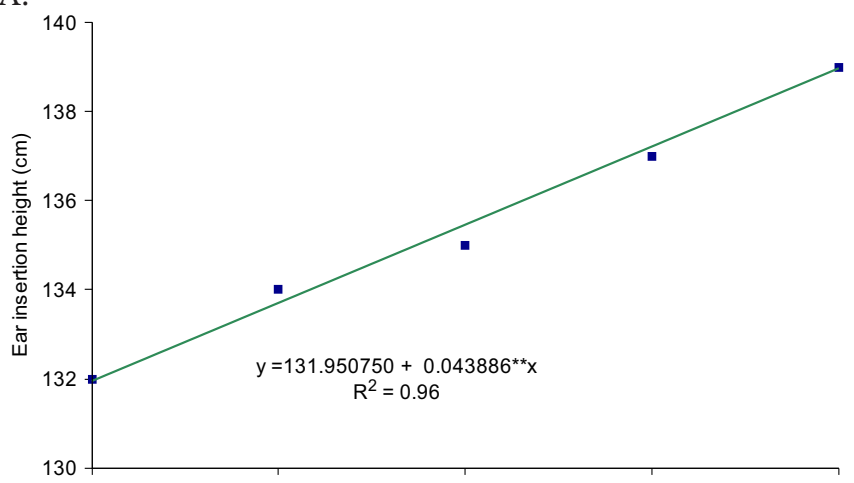

C.

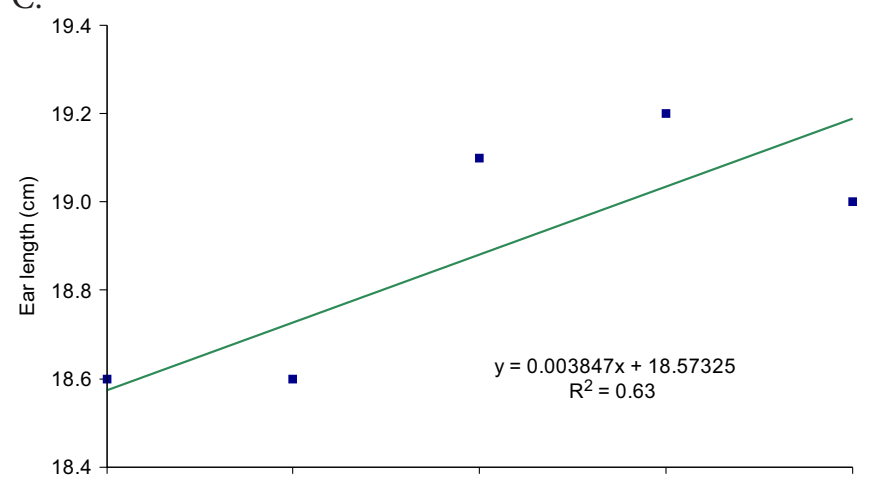

E.

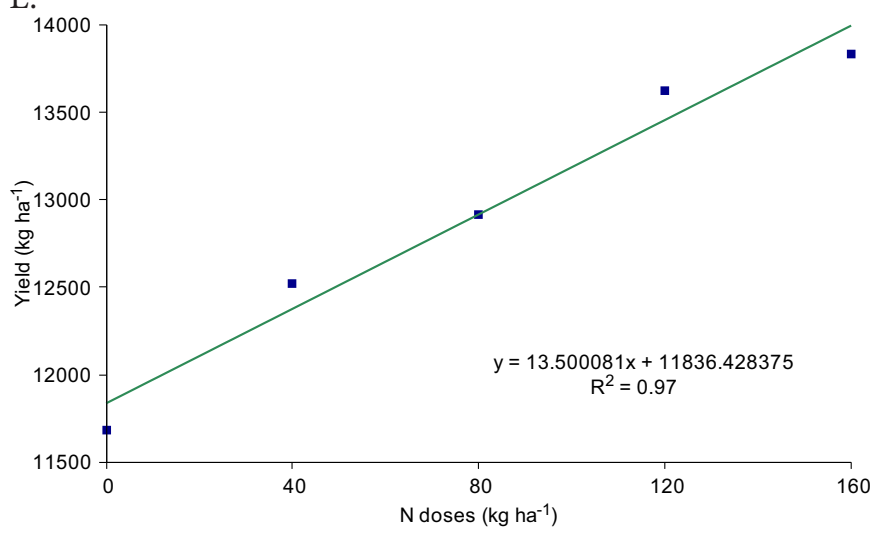

$* *$ Significant by Student's t-test $(\mathrm{p} \leq 0.01)$

Figure 2. Ear insertion height (A), ear weight (B), ear length $(\mathrm{F})$ of the maize hybrid 30R50, as a function of nitrogen $(\mathrm{N})$ fertilization and plant growth promotion, stimulating the absorption of the nutrient.

As to $\mathrm{K}$ contents, there was no effect of inoculation, with mean values of 52 and $15 \mathrm{~g} \mathrm{~kg}^{-1}$ of $\mathrm{K}$ for leaves and grains, respectively (Table 2 ). The observed leaf $\mathrm{K}$ content was higher than the maximum limit of the nutritional range (17.5 to $22.5 \mathrm{~g}$ $\mathrm{kg}^{-1}$ ) considered as adequate for maize by Malavolta et al. (1997).

$\mathrm{N}$ fertilization influenced ear insertion height, which showed an increasing linear response $(\mathrm{p} \leq 0.01)$ to $\mathrm{N}$ doses, with increment of $0.04 \mathrm{~cm}$ for each $\mathrm{kg}$ of $\mathrm{N}$ added to the soil (Figure 2A). This result corroborates those reported by Lana et al. (2009), who observed increasing linear response of ear insertion height as a function of increasing $\mathrm{N}$ doses, with increment of $0.06 \mathrm{~cm}$ for each $\mathrm{kg}$ of $\mathrm{N}$ added.

As to ear weight, the data showed an increasing linear response $(\mathrm{p} \leq 0.01)$ as a function of $\mathrm{N}$ fertilization, with increment of $0.18 \mathrm{~g}$ for each $\mathrm{kg}$ of $\mathrm{N}$ added to the soil (Figure $2 \mathrm{~B})$. There was also an increasing linear response of ear length $(\mathrm{p} \leq 0.01)$ and diameter $(\mathrm{p} \leq 0.01)$, with increments of 0.004

B.

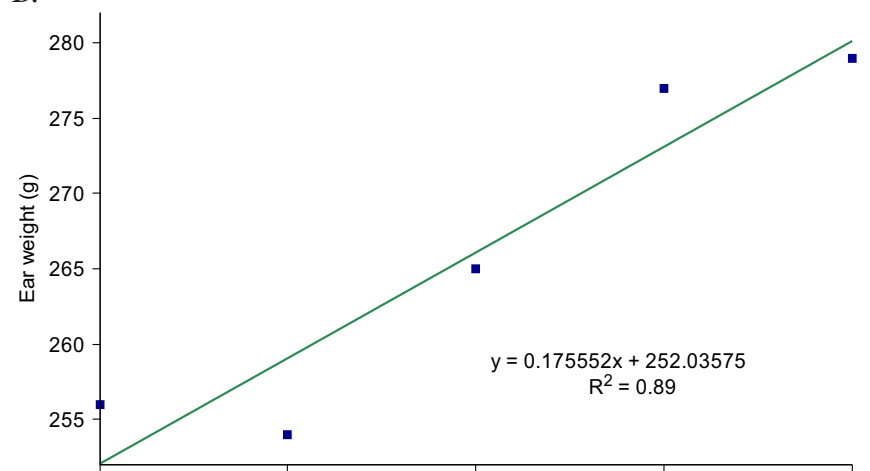

D.

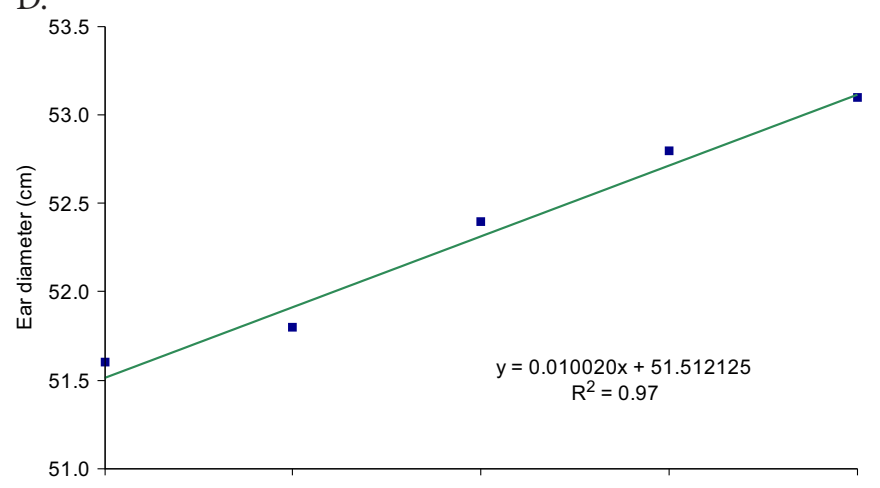

F.

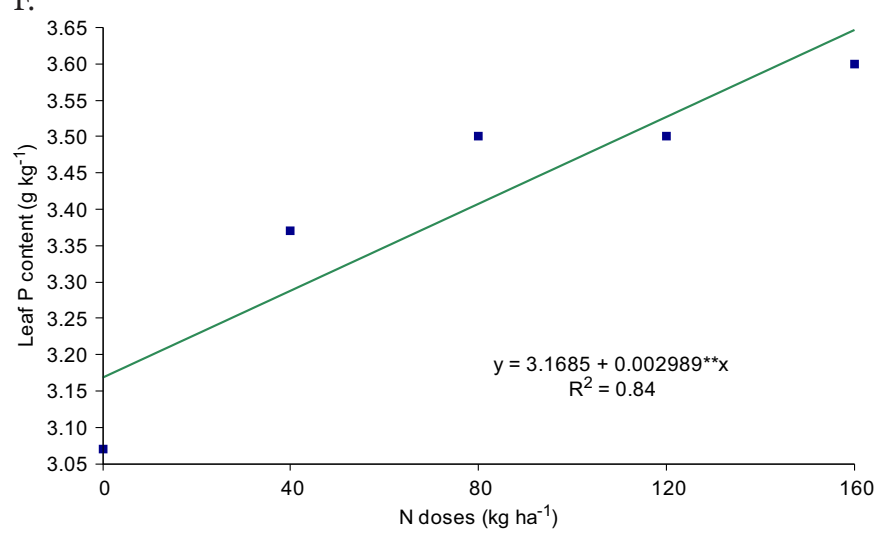


$\mathrm{cm}$ in length and $0.01 \mathrm{~cm}$ in diameter for each $\mathrm{kg}$ of $\mathrm{N}$ added (Figure 2C and 2D), contributing to the increase in crop yield (Büll, 1993).

An increasing linear response was observed for grain yield $(\mathrm{p} \leq 0.01)$ as a function of $\mathrm{N}$ fertilization, with increment of 13.5 $\mathrm{kg} \mathrm{ha}^{-1}$ for each $\mathrm{kg}$ of $\mathrm{N}$ added to the soil, although the highest $\mathrm{N}$ doses tested $\left(160 \mathrm{~kg} \mathrm{ha}^{-1}\right)$ did not promote alteration in the slope of the production curve (Figure $2 \mathrm{E}$ ). Thus, for every 40 $\mathrm{kg} \mathrm{ha}^{-1}$ of $\mathrm{N}$ added to the soil, there was an increment of 540 $\mathrm{kg} \mathrm{ha}^{-1}$ or 9 sacks ha $^{-1}$, benefiting the production system. Duete et al. (2008) and Gava et al. (2010) also observed increasing linear response of grain yield as a function of $\mathrm{N}$ fertilization in maize until the highest $\mathrm{N}$ doses tested (175 and $200 \mathrm{~kg} \mathrm{ha}^{-1}$ ). Ferreira et al. (2009), however, observed that the application of $120 \mathrm{~kg} \mathrm{ha}^{-1}$ of $\mathrm{N}$ reached $98.6 \%$ of the maximum yield obtained for maize $\left(10,553 \mathrm{~kg} \mathrm{ha}^{-1}\right)$.

The positive response of production components to $\mathrm{N}$ fertilization confirms the direct effect of $\mathrm{N}$ on maize development and yield. $\mathrm{N}$ fertilization favors plant growth, promoting increase in the photosynthetically active leaf area, which leads to greater synthesis and translocation of photoassimilates (Büll, 1993) from vegetative organs to the grains, resulting in higher yield. Additionally, the availability of $\mathrm{N}$ represents one of the factors that directly influence the number of ovaries and ovules contained in the ears, which are directly responsible for grain formation (Uhart \& Andrade, 1995).

$\mathrm{N}$ fertilization did not influence $\mathrm{N}$ and $\mathrm{K}$ contents in the leaves or $\mathrm{N}, \mathrm{P}$ and $\mathrm{K}$ contents in the grains. The absence of response of leaf $\mathrm{N}$ content to $\mathrm{N}$ fertilization can be attributed to a factor of dilution caused by the continuous plant growth, which culminates in the reduction of the percentage of $\mathrm{N}$ in maize shoots along the cycle.

There was significant effect of $\mathrm{N}$ fertilization on leaf $\mathrm{P}$ content, with increasing linear response of the data as a function of $\mathrm{N}$ doses and increment of $0.003 \mathrm{~g} \mathrm{~kg}^{-1}$ of $\mathrm{P}$ for each $\mathrm{kg}$ of $\mathrm{N}$ added to the soil (Figure 2F). This increment reflects the effect of $\mathrm{N}$ on plant growth, favoring the absorption of $\mathrm{P}$ from the soil and its availability to the plant, acting together with the phenomena of energy storage and transfer of energy in the plant in the form of ATP (Fornasieri Filho, 1992).

\section{Conclusions}

1. There was no interaction between the studied factors or influence of inoculation on grain yield.

2. Co-inoculation of $A$. brasilense and $H$. seropedicae promoted increment of $12 \%$ in leaf $\mathrm{P}$ content in relation to the control.

3. The application of increasing $\mathrm{N}$ doses as top-dressing promoted increment in grain yield and leaf $\mathrm{P}$ content in maize until the $\mathrm{N}$ dose of $160 \mathrm{~kg} \mathrm{ha}^{-1}$.

\section{ACKNOWLEDgments}

To the Araucária Foundation of Support for Scientific and Technological Development of Paraná, affiliated to the State Secretariat of Science, Technology and Higher Education -
SETI, to the Coordination for the Improvement of Higher Education Personnel (CAPES/PNPD) and the National Council for Scientific and Technological Development (CNPq/ INCT), for the financial support.

\section{Literature Cited}

Albuquerque, A. W.; Santos, J. R.; Moura Filho, G.; Reis, L. S. Plantas de cobertura e adubação nitrogenada na produção de milho em sistema de plantio direto. Revista Brasileira de Engenharia Agrícola e Ambiental, v.17, p.721-726, 2013. http://dx.doi. org/10.1590/S1415-43662013000700005

Alves, G. C.; Videira, S. S.; Urquiaga, S.; Reis, V. M. Differential plant growth promotion and nitrogen fixation in two genotypes of maize by several Herbaspirillum inoculants. Plant Soil, v.387, p.307-321, 2015. http://dx.doi.org/10.1007/s11104-014-2295-2

Bárbaro, I. M.; Brancalião, S. R.; Ticelli, M. É possível a fixação biológica de nitrogênio no milho? Pesquisa e Tecnologia, v.5, p.1-8, 2008.

Bashan, Y.; De-Bashan, L. E. How the plant growth-promoting bacterium Azospirillum promotes plant growth - a critical assessment 2010. Advances in Agronomy, v.108, p.77-136, 2010. http://dx.doi.org/10.1016/S0065-2113(10)08002-8

Bashan, Y.; Holguin, G. Azospirillum-plant relationships: environmental and physiological advances (1990-1996). Canadian Journal of Microbiology, v.43, p.103-121, 1997. http://dx.doi. org/10.1139/m97-015

Braga, J. M.; Defelipo, B. V. Determinação espectrofotométrica de fósforo em extratos de solo e material vegetal. Revista Ceres, v.21, p.73-85, 1974.

Büll, L. T. Nutrição mineral do milho. In: Bull, L. T.; Cantarella, H. (ed.). Cultura do milho: Fatores que afetam a produtividade. Piracicaba: POTAFOS, 1993. p.63-131.

Casagrande, J. R. R.; Fornasieri Filho, D. Adubação nitrogenada na cultura do milho safrinha. Pesquisa Agropecuária Brasileira, v.37, p.33-40, 2002. http://dx.doi.org/10.1590/S0100204X2002000100005

Dobbelaere, S.; Vanderleyden, J.; Okon, Y. Plant growth-promoting effects of diazotrophs in the rhizosphere. Critical Reviews in Plant Sciences, v.22, p.107-149, 2003. http://dx.doi. org/10.1080/713610853

Dotto, A. P.; Lana, M. do C.; Steiner, F.; Frandoloso, J. F. Produtividade do milho em resposta à inoculação com Herbaspirillum seropedicae sob diferentes níveis de nitrogênio. Revista Brasileira de Ciências Agrárias, v.5, p.376-382, 2010. http://dx.doi.org/10.5039/agraria. v5i3a898

Duete, R. R. C.; Muraoka, T.; Silva, E. C. da; Trivelin, P. C. O.; Ambrosano, E. J. Manejo da adubação nitrogenada e utilização do Nitrogênio (15N) pelo milho em Latossolo Vermelho. Revista Brasileira de Ciência do Solo, v.32, p.161-171, 2008. http://dx.doi. org/10.1590/S0100-06832008000100016

Ferreira, A. de. O.; SÁ, J. C. de M.; Briedis, C.; Figueiredo, A. G. de. Desempenho de genótipos de milho cultivados com diferentes quantidades de palha de aveia-preta e doses de nitrogênio. Pesquisa Agropecuária Brasileira, v.44, p.173-179, 2009. http:// dx.doi.org/10.1590/S0100-204X2009000200009

Ferreira, D. F. Sisvar: Um programa para análises e ensino de estatística. Revista Symposium, v.6, p.36-41, 2008. 
Fornasieri Filho, D. A cultura do milho. Jaboticabal: FUNEP, 1992. $273 p$.

Gava, G. J. de C.; Oliveira, M. W. de; Silva, M. de A.; Jerônimo, E. M.; Cruz, J. C. S.; Trivelin, P. C. O. Produção de fitomassa e acúmulo de nitrogênio em milho cultivado com diferentes doses de $15 \mathrm{~N}$-uréia. Semina, v.31, p.851-862, 2010. http://dx.doi.org/10.5433/16790359.2010v31n4p851

Hungria, M; Campo, R. J.; Souza, E. M.; Pedrosa, F. Inoculation with selected strains of Azospirillum brasilense and A. lipoferum improves yields of maize and wheat in Brazil. Plant Soil, v.331, p.413-425, 2010. http://dx.doi.org/10.1007/s11104-009-0262-0

Kennedy, I. R; Pereg-Gerk, L. L; Wood, C; Deaker, R; Gilchrst, K; Katupitiya, S. Biological nitrogen fixation in nonlegumes field crops: Facilitating the evolution of in effective association between Azospirillum and wheat. Plant and Soil, v.194, p.65-79, 1997. http://dx.doi.org/10.1023/A:1004260222528

Lana, M. C.; Woytichoski Júnior, P. P.; Braccini, A. L.; Scapim, C. A.; Ávila, M. R.; Albrecht, L. P. Arranjo espacial e adubação nitrogenada em cobertura na cultura do milho. Acta Scientiarum. Agronomy, v.31, p.433-438, 2009.

Lana, M. do C.; Dartora, J.; Marini, D.; Hann, J. E. H. Inoculation with Azospirillum, associated with nitrogen fertilization in maize. Revista Ceres, v.59, p.399-405, 2012. http://dx.doi.org/10.1590/ S0034-737X2012000300016
Malavolta, E; Vitti, G. C; Oliveira, S. A. de. Avaliação do estado nutricional das plantas: princípios e aplicações. Piracicaba: POTAFOS, 1997. 319p.

Monteiro, R. A.; Schmidt, M. A.; Baura, V. A. de; Balsanelli, E.; Wassem, R.; Yates, M. G.; Randi, M. A. F.; Pedrosa, F. O.; E. M. de Souza. Early colonization pattern of maize (Zea mays L. Poales, Poaceae) roots by Herbaspirillum seropedicae (Burkholderiales, Oxalobacteraceae). Genetics and Molecular Biology, v.31, p.932937, 2008. http://dx.doi.org/10.1590/S1415-47572008000500021 Reis Júnior, F. B.; Machado, C. T. de T.; Machado, A. T.; Mendes, I. de C.; Mehta, A. Isolamento, caracterização e seleção de estirpes de Azospirillum amazonense e Herbaspirillum seropediceae associadas a diferentes variedades de milho cultivadas no Cerrado. Planaltina: Empresa Brasileira de Pesquisa Agropecuária, 2008. 36p. Boletim de Pesquisa e Desenvolvimento, 206

SEAB - Secretaria da Agricultura e do Abastecimento. <http://www. agricultura.pr.gov.br>. 2 Set. 2011.

Tedesco, M. J. Gianello, C.; Bissani, C. A.; Bohnen, H.; Volkweiss, S. J. Análises de solo, plantas e outros materiais. 2.ed. Porto Alegre: Universidade Federal do Rio Grande do Sul, 1995. 174p. Boletim Técnico, 5

Uhart, S. A.; Andrade, F. H. Nitrogen deficiency in maize. I. Effects on crops growth, development, dry matter partitioning, and kernel set. Crop Science, v.35, p.1376-1383, 1995. http://dx.doi. org/10.2135/cropsci1995.0011183X003500050020x 